JIIA, VOLUME 8 No.1, FEBRUARI 2020

\title{
PENGARUH HAMBATAN NONTARIF DI PASAR UNI EROPA TERHADAP EKSPOR KOMODITAS CPO INDONESIA
}

\author{
(Effect Of Non-tariff Barrier In The European Union Market Toward The Indonesian Export Of Crude \\ Palm Oil Commodity)
}

Satria Arif Gumelar, Muhammad Irfan Affandi, Suriaty Situmorang

Jurusan Agribisnis, Fakultas Pertanian, Universitas Lampung, Jl. Prof. Dr. Soemantri Brojonegoro No. 1 Bandar Lampung, 35145, e-mail: irfan.affandi@fp.unila.ac.id

\begin{abstract}
This research aims to analyze which trade barriers are implemented by European Union (EU) on Indonesian Crude Palm Oil (CPO) commodity and did the non-tariff barrier named "Report on Palm Oil and Deforestation of Rainforrest" which has been ratified by the European Comission (EC) have a significant effects on Indonesian CPO export or not. This research used literature study method with secondary and primary data obtained from BPS, Indonesian National Export Development Agency, Central Bank of Indonesia, Eurostat, WTO, FAO, PASPI, Indonesian Ministry of Agriculture, Indonesian Ministry of Trade and Indonesian Palm Oil Assosiation (IPOA). The results of this research show that the EU has implemented non-tariff barriers on Indonesian CPO since 1905 with various kinds of issues such as health, social and environment. The non-tariff barrier which has been ratified in April 2017 by the European Comission did not significantly affect on Indonesian CPO export.
\end{abstract}

Key words: CPO, European Union, Non-tariff Barriers.

\section{PENDAHULUAN}

Indonesia sebagai negara agraris memiliki potensi besar dalam bidang pertanian.Salah satu subsektor yang paling potensial adalah perkebunan. Kemewahan hasil perkebunan Indonesia,seperti :rempah-rempah, kopi, teh, karet, tembakau dan lain sebagainya, di masa lampau telah menarik perhatian dan menjadi motivasi utama bangsabangsa Eropa untuk datang ke Indonesia dan memonopoli perdagangan (Ditjenbun2013). Hal tersebut menunjukkan bahwa sektor perkebunan merupakan sektor yang memiliki peran penting dalam pengembangan pembangunan perekonomian di Indonesia.

Subsektor perkebunan merupakan salah satu andalan bagi pendapatan nasional dan devisa negara, mengingat kontribusinya yang sangat besar, antara lain pada tahun 2013 mencapai US\$ 45,54 milyar atau setara dengan Rp.546,42 trilliun, meliputi ekspor komoditas perkebunan sebesar US\$ 35,64 milyar, cukai hasil tembakau US\$ 8,63 millyar, dan bea keluar (BK) kelapa sawit dan biji kakao sebesar US\$1,26 milyar. Jika dibandingkan dengan tahun 2012, maka kontribusi subsektor perkebunan mengalami peningkatan sebesar 27,78 persen atau naik sebesar US\$ 9,90 milyar (Ditjenbun 2015).
Salah satu komoditas yang cukup berperan dalam ekspor perkebunan adalah kelapa sawit.Kelapa sawit merupakan salah satu komoditas unggulan Indonesia dalam perdagangan internasional. Menurut Kementerian Perdagangan (2017) komoditas sawit menyumbang 12,70persen dari jumlah total ekspor non migas pada tahun 2017.

Total volume ekspor CPO Indonesia mengalami kenaikan dari tahun 2012 sampai tahun 2015. Meskipun mengalami sedikit penurunan pada tahun 2016.Penurunan ekspor tersebut tetap tidak bisa membantah bahwa kelapa sawit memiliki potensi yang cukup tinggi di pasar internasional (Ditjenbun2015).Hal ini didukung dengan produksi CPO Indonesia dari tahun 2012 hingga 2017 yang selalu meningkat setiap tahunnya, sehingga potensi menambah volume ekspor juga semakin besar. Ekspor minyak sawit Indonesia dipengaruhi oleh beberapa variabel, antara lain produksi di dalam negeri, harga di pasar domestik, dan nilai tukar terhadap dollar AS (Maygirtasari, Yulianto, dan Mawardi 2015).

Pangsa pasar kelapa sawit Indonesia saat ini tidak hanya terfokus pada kawasan Asia saja, namun sudah mulai berkembang ke kawasan Timur Tengah, Uni Eropa dan bahkan Afrika.Dari beberapa pasar tersebut, Uni Eropa merupakan yang paling potensial. Semakin banyaknya 
perusahaan-perusahaan di Eropa yang membutuhkan minyak nabati sebagai bahan baku industri dan biofuel, merupakanalasan utama semakin tingginya volume impor kelapa sawit yang dilakukan Uni Eropa (Dhiga 2016). Hal itu dibuktikan dengan meningkatnya volume impor kelapa sawit Uni Eropa beberapa tahun terakhir.

Impor minyak kelapa sawit Uni Eropa dari tahun 2010 sampai tahun 2013 terus mengalami kenaikan dengan volume ekspor tertinggi mencapai 6.969.000 ton. Pada tahun 2013 sampai 2017, volume impor minyak kelapa sawit Uni Eropa mulai turun sedikit demi sedikit.Penurunan impor minyak kelapa sawit oleh Uni Eropa tersebut diakibatkan oleh 2 hal, yaitu kebijakan hambatan tarif dan hambatan nontarif yang diterapkan oleh Uni Eropa. Hambatan tarif merupakan pungutan bea masuk yang dikenakan atas barang impor yang masuk untuk dipakai/dikonsumsi di dalam negeri, sedangkan hambatan nontarif adalah hambatan perdagangan dalam bentuk kebijakan, peraturan, maupun prosedur yang mengubah perdagangan (Hady2004).

Salah satu yang menjadi isu internasional bagi ekspor minyak sawit ke Uni Eropa saat ini adalah resolusi sawit Uni Eropa yang bertajuk "Report on Palm Oil and Deforestation of Rainforest" yang di dalamnya disebutkan bahwa parlemen Uni Eropa melarang pemakaian biodiesel berbasis minyak kelapa sawit mulai tahun 2020 mendatang, dan akan memberlakukan sertifikasi tunggal bagi kelapa sawit (Gumelar 2017). Resolusi ini dibuat karena proses produksi minyak kelapa sawit dianggap sebagai masalah lingkungan dan keluar dari prinsip keberlanjutan. Selain itu, resolusi tersebut juga dibuat untuk melindungi komoditas lokal yang sulit bersaing akibat masuknya minyak kelapa sawit ke pasar Uni Eropa.Kebijakan tersebut tentunya akan sangat merugikan bagi Indonesia, mengingat Indonesia adalah eksportir minyak kelapa sawit terbesar di dunia dan Uni Eropa merupakan salah satu pasar terbesarnya. Resolusi sawit Uni Eropa dianggap akan menjadi hambatan perdagangan nontarif baru yang cukup berdampak terhadap volume ekspor Indonesia ke Uni Eropa, di samping hambatan tarif yang sudah ada selama ini.

Berdasarkan kondisi tersebut, maka sangat relevan untuk menganalisis pengaruh hambatan nontarif di pasar Uni Eropa terhadap ekspor komoditas CPO Indonesia. Tujuan dari penelitian ini adalah untuk mengetahui hambatan tarif dan nontarif dalam perdagangan $\mathrm{CPO}$ Indonesia ke Uni Eropa, apakah hambatan nontarif yang bertajuk "Report on palm oil and deforestation of rainforest" berpengaruh secara signifikan terhadap volume ekspor CPO Indonesia.

\section{METODE PENELITIAN}

Penelitian ini menggunakan metode korelasional.Metode korelasional adalah suatu penelitian untuk mengetahui hubungan dan tingkat hubungan antara dua variabel atau lebih tanpa ada upaya untuk mempengaruhi variabel tersebut sehingga tidak terdapat manipulasi variabel (Fraenkel dan Wallen2008).Data yang dikumpulkan adalah datasekunder dari tahun 2014 - 2017.Data diperoleh dari instansi dan literatur yang terkait dengan penelitian ini, seperti Bank Indonesia, Badan Pusat Statistik (BPS), Eurostat, World Trade Organization (WTO), Food and Agriculture Organization (FAO), Kementerian Pertanian Republik Indonesia, dan Palm Oil Agribusiness Strategic Policy Institute (PASPI).Data tersebut mencakup data jumlah volume ekspor CPO Indonesia, volume produksi CPO Indonesia, nilai ekspor CPO Indonesia, jumlah produksi CPO Indonesia, harga CPO di pasar lokal dan dunia, serta nilai tukar rupiah terhadap dollar, serta arsip-arsip peraturan dan regulasi perdagangan Uni Eropa, dan data lainnya yang mendukung penelitian ini.Sebaran data yang digunakan dan sumbernya di tampilkan pada Tabel 1. Untuk mendukung data yang telah didapatkan, dilakukan wawancara dengan Gabungan Pengusaha Kelapa Sawit Indonesia (GAPKI), dan Kementerian Perdagangan Republik Indonesia yang mewakili pelaku usaha dan stake holder yang bergerak langsung di bidang perdagangan CPO.

Tabel 1.Sebaran data penelitian dan sumbernya.

\begin{tabular}{|c|c|c|c|}
\hline No. & Data & Tahun & Sumber \\
\hline 1 & $\begin{array}{l}\text { Volume ekspor } \\
\text { CPO Indonesia }\end{array}$ & 2014-2017 & BPS \\
\hline 2 & $\begin{array}{l}\text { Nilai ekspor } \\
\text { CPO Indonesia }\end{array}$ & 2014-2017 & BPS \\
\hline 3 & $\begin{array}{l}\text { Harga CPO } \\
\text { domestik }\end{array}$ & 2014-2017 & BPS \\
\hline 4 & $\begin{array}{l}\text { Harga CPO } \\
\text { internasional }\end{array}$ & 2014-2017 & USDA \\
\hline 5 & $\begin{array}{l}\text { Nilai tukar } \\
\text { rupiah terhadap } \\
\text { dollar }\end{array}$ & 2014-2017 & Bank Indonesia \\
\hline 6 & $\begin{array}{l}\text { Hambatan tarif, } \\
\text { dan nontarif } \\
\text { CPO oleh Uni } \\
\text { Eropa }\end{array}$ & $1905-2017$ & $\begin{array}{l}\text { European } \\
\text { Commision, } \\
\text { PASPI, FAO, } \\
\text { WTO dll. }\end{array}$ \\
\hline
\end{tabular}




\section{Metode Analisis Data}

Untuk mengetahui hambatan tarif dan nontarif oleh Uni Eropa dalam perdagangan CPO, maka dilakukan analisis deskriptif kualitatif dengan mempelajari dokumen-dokumen yang berkaitan dengan kebijakan perdagangan internasional yang dikeluarkan oleh Uni Eropa tentang hambatan perdagangan nontarif.

Untuk mengetahui pengaruh hambatan nontarif terhadap ekspor CPO Indonesia ke Uni Eropa, maka dilakukan analisis data statistik, yaitu pengolahan data dengan analisis regresi. Model yang digunakan dalam penelitian ini adalah model regresi berganda dengan variabel dummy, berupa persamaan:

$\mathrm{Y}=\mathrm{a}+\mathrm{b}_{1} \mathrm{X}_{1}+\mathrm{b}_{2} \mathrm{X}_{2}+\mathrm{b}_{3} \mathrm{X}_{3}+\mathrm{b}_{4} \mathrm{D}+\mathrm{e}$

Keterangan:

$\mathrm{Y}=$ Volume ekspor CPO Indonesia ke Uni Eropa (ton)

a $=$ Konstanta

$\mathrm{b}=$ Koefisien regresi

$\mathrm{X}_{1}=$ Indeks harga CPO di Indonesia (Rp)

$\mathrm{X}_{2}=$ Indeks harga CPO di pasar internasional (US\$)

$\mathrm{X}_{3}=$ Nilai tukar rupiah terhadap dollar AS (Rp)

$\mathrm{D}=$ Dummy kebijakan hambatan nontarif $1=$ Setelah resolusi sawit Uni Eropa

$0=$ Sebelum resolusi sawit Uni Eropa

e $=$ Error

Setelah mendapatkan data dari masing-masing variabel, dilakukkan uji stasioneritas untuk mengetahui apakah data yang didapat stasioner atau tidak. Dari hasil uji stasioneritas didapatkanhasil bahwa variabel $\mathrm{X}_{1}, \mathrm{X}_{2}, \mathrm{X}_{3}$ tidak stasioner. Untuk menstasionerkan variabel $\mathrm{X}_{1}, \mathrm{X}_{2}$, $\mathrm{X}_{3}$, menurut Munawaroh (2010) data harus dikonversikan menjadi deret stasioner melalui diferensiasi, jumlah diferensiasi yang dilakukan untuk mencapai stasioner dinotasikan sebagai $d$, sehingga bentuk persamaan yang digunakan setelah didiferensiasi adalah :

$d(Y)=a+d\left(b_{1} X_{1}\right)+d\left(b_{2} X_{2}\right)+d\left(b_{3} X_{3}\right)+b_{4} D_{1}+e \ldots$.

Keterangan :

$\mathrm{Y}=$ Volume ekspor CPO Indonesia ke Uni Eropa

$\mathrm{a}=$ Konstanta

$\mathrm{b}=$ Koefisien regresi

$\mathrm{X}_{1}=$ Indeks Harga CPO di Indonesia (Rp)

$\mathrm{X}_{2}=$ Indeks Harga CPO di pasar internasional (US\$)
$\mathrm{X}_{3}=$ Nilai tukar rupiah terhadap dollar AS (Rp)

$\mathrm{D}=$ Dummy kebijakan hambatan nontarif

$1=$ Setelah resolusi sawit Uni Eropa

$0=$ Sebelum resolusi sawit Uni Eropa

$\mathrm{d}=$ diferensiasi

e $=$ Error

Hasil analisis regresi diuji lagi dengan uji $\mathrm{F}$ dan uji $\mathrm{t}$ untuk mengetahui apakah ada pengaruh antara variabel bebas dan variabel terikat. Uji asumsi klasik juga dilakukan untuk mengetahui apakah persamaan tersebut dapat digunakan untuk mengetahui apakah estimasi yang diperoleh bersifat $B L U E$ atau tidak. Pengujian dilakukan dengan menggunakan $\alpha=5 \%$ (selang kepercayaan $=95 \%$ ) dengan menggunakan aplikasi eviewes 9 .

\section{HASIL DAN PEMBAHASAN}

Data variabel yang digunakan pada penelitian ini antara lain harga CPO di pasar domestik $\left(\mathrm{X}_{1}\right)$, harga CPO di pasar internasional $\left(\mathrm{X}_{2}\right)$, nilai tukar rupiah terhadap dolar $\left(\mathrm{X}_{3}\right)$, hambatan nontarif yang bertajjuk "Report on palm oil and deforestation of rainforest" yang mulai diberlakukan oleh Uni Eropa pada April 2017 sebagai variabel dummy $\left(D_{1}\right)$, serta volume ekspor CPO Indonesia sebagai variabel terikat (Y). Data yang digunakan adalah data perbulan dari tahun 2014 sampai 2017. Selain data tersebut, untuk mendukung hasil penelitian ini, dilakukan wawancara dengan GAPKI dan Kementerian Perdagangan sebagai pelaku usaha dan stake holder di bidang perdagangan CPO.

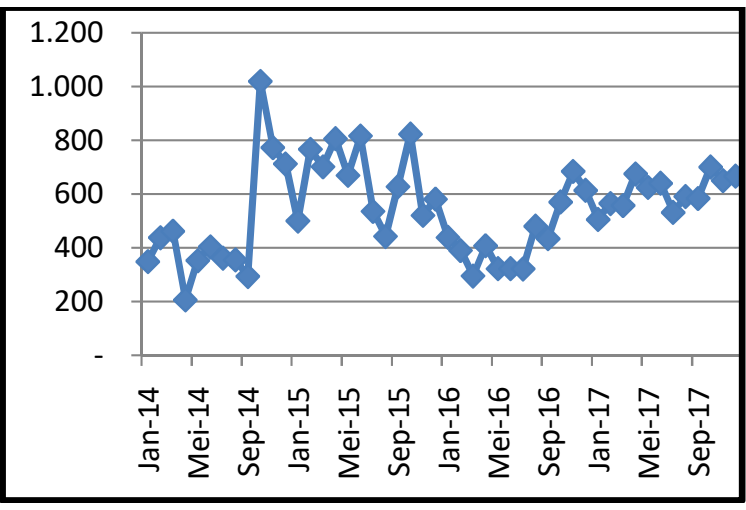

Gambar 1. Grafik Volume Ekspor CPO Indonesia tahun 2014-2017

Sumber : BPS 2017

Dari data yang telah didapatkan, dapat dilihat pada Gambar 1 bahwa volume ekspor CPO Indonesia dari tahun 2014 hingga 2017 memiliki tren pergerakan yang cukup positif meskipun tingkat 
fuktuasinya cukup tinggi. Hal ini berbanding terbalik dengan data harga di pasar internasional yang justru memiliiki tren penurunan sejak 2014 sampai 2017, sementara tren harga di pasar domestik cenderung lebih stabil, meskipun pada tahun 2015 dan 2016 mengalami penurunan yang cukup signifikan. Nilai tukar rupiah terhadap dollar sejak tahun 2014 hingga 2017 mengalami pelemahan sebanyak 1.377 point, yaitu dari 12.179 menjadi 13.556 rupiah per dollar Amerika Serikat.

\section{Hambatan Tarif dan Nontarif CPO dipasar Uni Eropa}

Hambatan tarif adalah hambatan untuk memasuki suatu pasar dalam perdagangan internasional, yang biasa dibebankan dalam bentuk biaya dansering juga disebut sebagai bea masuk. Hambatan nontarif atau hambatan teknis adalah hambatan yang diberlakukan untuk mengurangi jumlah barang yang masuk,melalui : regulasi, peraturan, hingga kampanye-kampanye yang dilakukan, baik oleh pemerintah maupun nonpemeritah. Bea masuk yang diberlakukan oleh Uni Eropa sendiri memiliki tarif yang bervariasi sesuai kode harmoni dari masing-masing barang yang akan memasuki pasar Uni Eropa. Daftar tarif bea masuk minyak sawit Indonesia meurut kode harmoninya disajikan pada Tabel 2. Dalam perdagangan minyak sawit di Uni Eropa, bea masuk yang diberlakukan terbagi menjadi dua, yaitu Crude Palm Oil dan Other Palm Oil. Dalam kategori Crude Palm Oil, bea masuk terbagi lagi menjadi dua, yaitu "untuk keperluan teknis dan industri" dan "untuk keperluan lainnya". Pada kategori Other Palm Oil, bea masuk dibagi menjadi fraksi padat dan jenis lainnya. Fraksi padat dibagi lagi menjadi "dalam kemasan tidak lebih dari $1 \mathrm{~kg}$ " dan "kemasan

Tabel 2. Daftar tarif bea masuk minyak sawit Indonesia ke Uni Eropa, tahun 2016

\begin{tabular}{ccc}
\hline Kode HS & $\begin{array}{c}\text { Tarif bea masuk Uni } \\
\text { Eropa (\%) }\end{array}$ & $\begin{array}{c}\text { Regulasi yang } \\
\text { diberlakukan }\end{array}$ \\
\hline 1511101000 & 0,0 & R0615490 \\
1511109000 & 3,8 & R9922040 \\
1511901100 & 12,8 & R9922040 \\
1511909120 & 5,1 & R0615490 \\
\hline
\end{tabular}

Sumber : European Commission 2017

Keterangan:

$1511101000=\mathrm{CPO}$ untuk keperluan teknis dan industri

$1511109000=\mathrm{CPO}$ yang digunakan untuk selain industri dan teknis

$1511901100=$ Fraksi padat dalam kemasan tidak lebih dari $1 \mathrm{~kg}$

$1511909120=$ Minyak Sawit lain untuk keperluan teknis dan industri lainnya", sementara pada jenis lainnya dibagi menjadi "untuk keperluan teknis dan industri kimia" dan "untuk keperluan lainnya". Dapat dilihat pada Tabel 2 bahwa CPO dengan kode HS 1511101000, yang digunakan untuk keperluan teknis dan industri, tidak dibebankan bea masuk ke Uni Eropa.

Hal tersebut sebenarnya membuktikan bahwa Uni Eropa membutuhkan CPO sebagai bahan untuk memenuhi kebutuhan teknis serta industrinya. Seperti diketahui, CPO dan turunannya biasa digunakan sebagai bahan baku dari berbagai produk industri, mulai dari minyak makan, margarin, sabun, shampo, pasta gigi, deterjen, coklat, es krim, selai, kosmetik, kue, roti, adonan pizza hingga biodisel menggunakan CPO sebagai campuran atau bahan bakunya. Uni Eropa yang dikenal sebagai salah satu pioner dalam berbagai industri tersebut tentu saja sangat membutuhkan CPO sebagai bahan baku industrinya, terlebih CPO memiliki hara yang lebih murah jika dibandingkan denganminyak nabati lainnya.

Tidak dibebankannya bea masuk untuk CPO dengan kode HS 1511101000 tidak serta merta membuat CPO Indonesia dapat dengan sangat mudah masuk ke Uni Eropa. Menurut Direktorat Pengamanan Perdagangan Kementerian Perdagangan Republik Indonesia, sejak tahun 1905, Uni Eropa telah mengeluarkan beberapa hambatan nontarif (teknis) terhadap produk olahan sawit Indonesia, berupa isu sosial, kesehatan, hingga lingkungan untuk mengurangi jumlah volume minyak sawit Indonesia ke Uni Eropa. Daftar hambatan teknis perdagangan yang pernah dikeluarkan Uni Eropa untuk minyak sawit Indonesia disajikan pada Tabel 3.

Daftar yang ada pada Tabel 3 belum termasuk kasus-kasus tuduhan dumping, subsidi, dan safeguard terhadap Indonesia oleh Uni Eropa. Selanjutnya, masih menurut Direktorat Pengaman Perdagangan, isu yang dikeluarkan Uni Eropa tersebut hanya sebagai bentuk perlindungan pemerintah terhadap pengusaha-pengusaha minyak nabati lokal yang eksistensinya terganggu dengan masuknya minyak sawit ke Uni Eropa.Sumber minyak nabati Uni Eropa sebelum minyak sawit masuk ke sana adalah Raped Seed Oil (RSO), Soy Been Oil (SBO) dan Sun Flower Oil (SFO). Hal tersebut didukung oleh informasi GAPKI yang menyatakan bahwa sebelum CPO masuk ke Uni Eropa, pasar minyak nabati Uni Eropa didominasi oleh RSO, SFO dan SBO yang diimpor dari Amerika, sehingga pada awal masuknya CPO ke 
Tabel 3. Daftar hambatan teknis (nontarif) dalam perdagangan minyak sawit Indonesia ke Uni Eropa tahun 1905 - 2017

\begin{tabular}{lc}
\hline \multicolumn{1}{c}{ Jenis hambatan teknis } & Inisiasi \\
\hline $\begin{array}{l}\text { Kampanye negatif terhadap Minyak } \\
\text { Sawit Indonesia }\end{array}$ & 07 Juli 1905 \\
$\begin{array}{l}\text { Sustainable Agricultural Practice - } \\
\text { Ferrero : Palm Oil }\end{array}$ & 01 Juni 2007 \\
Renewable Energy Direvtive (RED) & 23 April 2009 \\
RASFF Alert - Kandungan dioxins & \\
dalam fatty acid dari PT. Nagamas & \\
$\begin{array}{l}\text { Palmoil Lestari - Indonesia } \\
\text { RASFF Alert - Kandungan Salmonella }\end{array}$ & 18 Juni 2014 \\
$\begin{array}{l}\text { Ruiru dalam palm kernel oil Indonesia } \\
\text { Resolusi tentang Palm Oil and } \\
\text { Deforestation of Rainforests }\end{array}$ & 14 Juli 2014 \\
\hline
\end{tabular}

Sumber: Direktorat Pengamanan Perdagangan Kementerian Perdagangan Republik Indonesia 2018

Uni Eropa, CPO dilihat sebagai barang substitusi dari RSO, SFO dan SBO. Karena CPO memiliki harga yang relatif lebih murah, maka CPO dengan cepat mengalir deras ke Uni Eropa dan perlahan menggantikan produk minyak nabati lainnya. Sebagai contoh, pada tahun 2015, rasio harga $\mathrm{CPO} / \mathrm{RSO}$ adalah 0,67 , artinya dengan nilai untuk membeli 2 ton RSO bisa memperoleh 3 ton CPO. Hal ini tentu saja sangat menguntungkan Uni Eropa karena mendapat kelebihan minyak nabati sebesar 1 ton dari jumlah pengeluaran yang sama (GAPKI 2017).

Dari sisi produktivitas, CPO juga unggul dari RSO, SFO, dan SBO.Menurut Bidang Koordinasi Pangan dan Pertanian Kementerian Koordinator Bidang Perekonomian, CPO memiliki produktivitas paling tinggi dibandingkan dengan jenis minyak nabati lainnya. Produktivitas CPOyang mencapai 4 ton per ha jauh berada di atas RSO yang memiliki nilai produktivitas 0,7 ton per ha, SFO dengan produktivitas 0,6 ton per ha, dan SBO yang produktivitasnya hanya 0,4 ton per ha (Deny 2016). Alasan tersebutlah yang menurut Kementerian Perdagangan Republik Indonesia menjadi sebab utama pengusaha-pengusaha RSO, SFO, dan SBO untuk memaksa pemerintah Uni Eropa agar menolak masuknya CPO ke Uni Eropa melalui hambatan-hambatan teknis perdagangan. Hambatan teknis terbaru yang dikeluarkan Uni Eropa dan masih menjadi polemik sampai saat ini, adalah kelapa sawit sebagai penyebab deforestasi hutan.Para aktivis lingkungan Eropa menganggap bahwa kelapa sawit Indonesia menjadi penyebab pembukaan lahan di hutan hujan tropis sehingga bila tidak dihentikan, maka akan semakin luas hutan yang dialih fungsikan menjadi perkebunan sawit dan akan menjadi masalah lingkungan yang serius.

Berdasarkan wawancara dengan Direktorat Pengamanan Perdagangan Kementerian Perdagangan, masalah deforestasi hanya isu yang dibuat-buat untuk mengurangi minat penggunaan minyak sawit di dunia. Pernyataan tersebut didasari oleh fakta bahwa jauh sebelum Indonesia menanam kelapa sawit, negara-negara Eropa dan Amerika telah lebih dulu menebang hutan, baik hutan tropis maupun non tropis, untuk keperluan mereka. Hal tersebut sejalan dengan data dari Komisi Eropa dalam PASPI (2017), yang menyebutkan bahwa dalam periode 1990 sampai 2008, deforestasi global mencapai 239 juta ha, dari jumlah tersebut sekitar 33 persen terjadi di Amerika Selatan, dan 31 persen terjadi di Afrika, sedangkan Asia Tenggara, dimana Indonesia berada hanya sekitar 19 persen saja. Dengan permintaan minyak nabati dunia yang selalu bertambah setiap tahunnya, deforestasi justru dapat lebih buruk jika penggunaan CPO dihentikan dan kembali pada penggunaan RSO, SFO, dan SBO, karena dengan produktivitas yang rendah, tentu saja lahan yang dibutuhkan untuk memenuhi permintaan minyak nabati non sawit semakin luas, dan akan menyebabkan deforestasi yang lebih banyak lagi. Fakta-fakta tersebut membuktikan bahwa isu deforestasi yang ditujukan kepada kelapa sawit Indonesia tidak berdasar dan dibuat hanya untuk kepentingan perdagangan saja.

\section{Pengaruh Hambatan Nontarif (Teknis) Uni Eropa Terhadap Ekspor CPO Indonesia}

Meskipun kebijakan teknis yang dikeluarkan Uni Eropa tidak didasari fakta-fakta yang relevan, kebijakan tersebut tetap berpotensi mempengaruhi volume ekspor CPO Indonesia.Untuk mengetahui apakah hambatan teknis tersebut berpengaruh secara signifikan atau tidak, diperlukan analisis kuantitatif dengan menggunakan analisis data statistik.

Pada penelitian ini diasumsikan kebijakan teknis yang dikeluarkan oleh Uni Eropa hanya terkait masalah lingkungan yang bertajuk "Report on Palm Oil and Deforestation of Rainforest". Berdasarkan hasil regresi yang telah dilakukan, didapatkan hasil uji $\mathrm{F}$ dari model tersebut yang menunjukkan bahwa secara bersama-sama variabel $\mathrm{X}_{1}, \mathrm{X}_{2}, \mathrm{X}_{3}$, dan $\mathrm{D}_{1}$ nyata berpengaruh terhadap volume ekspor $\mathrm{CPO}$ Indonesia dengan tingkat kepercayaan $99 \%$. 
Tabel 4. Hasil regresi faktor-faktor yang mempengaruhi volume ekspor $\mathrm{CPO}$ Indonesia

\begin{tabular}{lrrr}
\hline \multicolumn{1}{c}{ Variabel } & Koefisien & t-statiktik & sign \\
\hline Konstanta & 10,35551 & 0,409532 & 0,684 \\
$\begin{array}{l}\text { Harga CPO di } \\
\text { Indonesia (X1) }\end{array}$ & $-8,524908$ & $-2,661159$ & 0,01 \\
$\begin{array}{l}\text { Harga CPO di pasar } \\
\text { internasional (X2) }\end{array}$ & 16,36462 & 2,8376651 & 0,00 \\
$\begin{array}{l}\text { Nilai tukar rupiah } \\
\text { terhadap dollar (X3) }\end{array}$ & 0,165484 & 1,505997 & 0,13 \\
$\begin{array}{l}\text { Kebijakan hambatan } \\
\text { nontariff (D) }\end{array}$ & 13,58962 & 0,237690 & 0,81 \\
\hline $\begin{array}{l}\mathrm{R}^{2} \\
\text { Adjusted R }\end{array}$ & 0,228242 & & \\
f-statistik & 0,154741 & & 0,02 \\
\hline
\end{tabular}

Sumber: Data primer diolah 2018

Hasil uji t menunjukkan bahwa variabel $\mathrm{X}_{1}$ dan $\mathrm{X}_{2}$ nyata berpengaruh terhadap volume ekspor $\mathrm{CPO}$ Indonesia dengan tingkat kepercayaan 99\%, sementara variabel $X_{3}$ dan $D_{1}$ tidak nyata berpengaruh terhadap volume ekspor $\mathrm{CPO}$ Indonesia. Hal ini menegaskan bahwa hambatan nontarif (teknis) $\left(\mathrm{D}_{1}\right)$ tidak berpengaruh secara signifikan terhadap volume ekspor CPO Indonesia.Hasil analisis regresi disajikan pada Tabel 4.

Hasil analisis regresi tersebut didukung oleh pernyataan Direktur Eksekutif GAPKI, yang menyatakan bahwa hambatan nontarif apapun yang dibuat oleh Uni Eropa, tidak akan berdampak secara signifikan terhadap ekspor CPO Indonesia selama harga minyak nabati lainnya tidak dapat bersaing dengan harga CPO. Hal ini terbukti dengan masih eksisnya minyak kelapa sawit di pasar minyak nabati dunia sampai saat ini, meskipun terus menerus diserang oleh kampanyekampanye negatif.

Hasil revisi regulasi tentang "Report on Palm Oil and Deforestation of Rainforest" Uni Eropa yang merubah waktu diberlakukannya dari tahun 2020 menjadi 2030 juga menunjukkan bahwa sebenarnya pemerintah Uni Eropa juga menyadari akan pentingnya CPO untuk Uni Eropa. Namun, berdasarkan wawancara denganDirektur Eksekutif GAPKI, hambatan nontarif ini tetap akan memiliki dampak bagi CPO Indonesia, antara lain yang paling terlihat saat ini, yaitu turunnya harga komoditas sawit di Indonesia sebagai akibat turunnya permintaan sawit di pasar dunia.

Dikeluarkannya regulasi tentang kelapa sawit oleh Uni Eropa berdasarkan wawancara dengan
Direktorat Pengamanan Perdagangan Kementerian Perdagangan merupakan formalitas saja, sebagai bentuk reaksi dari tuntutan para pengusaha minyak nabati di Uni Eropa.Uni Eropa bahkan tidak memiliki prosedur standar yang resmi terkait tanaman sawit baik hulu maupun hilir, sedangkan Indonesia telah lama menggunakan standar prosedur Indonesian Sustainable Palm Oil (ISPO) untuk mengatur standar operasional prosedur pada perusahaan-perusahaan sawit di Indonesia.

Hasil penelitian ini berbeda dengan hasil penelitian-penelitian sebelumnya. Penelitian Maygirtasari, Yulianto, dan Mawardi. (2015) tentang faktor-faktor yang mempengaruhi volume ekspor CPO Indonesia menyimpulkan bahwa variabel yang memperngaruhi volume ekspor $\mathrm{CPO}$ Indonesia secara signifikan antara lain adalah produksi CPO domestik, harga CPO domestik, dan nilai tukar rupiah, sementara harga $\mathrm{CPO}$ internasional tidak nyata berpengaruh. Penelitian Ewaldo (2015) dan Radifan (2014) juga menyimpulkan hasil yang berbeda. Penelitan Ewaldo (2015) menyimpulkan bahwa ekspor minyak sawit Indonesia dipengaruhi secara signifikan oleh harga ekspor CPO dan produksi domestik, sementara nilai tukar rupiah tidak nyata berpengaruh terhadap ekspor CPO Indonesia.Penelitian Radifan (2014)juga menyimpulkan bahwa produksi, nilai tukar rupiah teradap dollar, serta harga minyak mentah dunia dalam jangka panjang berpengaruh secara signifikan terhadap volume ekspor CPO Indonesia. Perbedaantersebut dapat terjadi karena beberapa hal, antara lain berbedanya model dan metode yang digunakan dalam analisis data, berbedanya sumber data yang digunakan dalam penelitian, serta waktu penelitian yang berbeda.

\section{KESIMPULAN}

Berdasarkan hasil penelitian yang telah dilakukan dapat disimpulkan bahwa hambatan tarif yang diberlakukan untuk produk CPO di Uni Eropa bervariasi antara $3,8-15$ persen dari total transaksi, akan tetapi, untuk CPO dengan harmoni 1511101000 tidak diberlakukan hambatan tarif. Banyak hambatan nontarif (teknis) yang diberlakukan Uni Eropa terhadap minyak sawit Indonesia, antara lain : RASFF Alert, Sustainable Agricultural Practice, Renewable Energy Directive (RED) dan yang terbaru adalah dengan resolusi sawit yang bertajuk "Report on Palm Oil and Deforestation of Rainforest". Hambatan nontarif (teknis) berupa resolusi sawit yang bertajuk "Report on Palm Oil and Deforestation of 
Rainforest" tidak nyata berpengaruh terhadap volume ekspor CPO Indonesia, namun menurut GAPKI, dalam jangka pendek akan berpengaruh terhadap harga komoditas sawit di Indonesia.

\section{DAFTAR PUSTAKA}

BPS [Badan Pusat Statistik]. 2017. Statistik Kelapa Sawit Indonesia 2017. BPS Indonesia. Jakarta.

Deny S. 2016. Ini Keunggulan CPO Dibanding Komoditas Minyak Nabati Lain. https:/ /www.liputan6.com/bisnis/readinikeunggula n-cpo-dibanding-komoditasminyak-nabatilain. [23 Oktober 2018].

Dhiga. 2016. Dinamika Ekspor Minyak Sawit Mentah (CPO) Indonesia Ke Uni Eropa Pasca Revolusi 2016/2022 Mengenai Minyak Sawit Dan Deforestasi Hutan Hujan Oleh Parlemen Eropa. https://dhibreevan. wordpress.com. [3 Januari 2018].

Ditjenbun [Direktorat Jendral Perkebunan]. 2013. Sejarah Perkebunan di Indonesia. Ditjenbun. Jakarta.

. 2015. Peran Perkebunan Dalam Pembangunan Nasional. Ditjenbun. Jakarta.

European Commission.2017. European Union

Tariffs. http://madb.europa.eu/ madb/euTariffs.htm?productCode $=1511909$ 120\&country.[23 Oktober 2018].

Ewaldo E. 2015. Analisis ekspor minyak kelapa sawit di Indonesia. e-jurnal perdagangan, industri, dan moneter, 3(1). https://onlinejournal.unja.ac.id/index.php/pim/article/dow nload/3988/2904.[20 Februari 2018].

Fraenkel JR dan Wellen NE. 2008. How to Design and Evaluate research in Education. McGraw-Hill. New York.
GAPKI [Gabungan Pengusaha Kelapa Sawit Indonesia]. 2017. Supply-Demand Minyak Nabati Uni Eropa : Apakah Resolusi Sawit Mudah Diimplementasikan?. https://gapki. $\mathrm{id} /$ news/2491/supply-demand-minyaknabati-uni-eropa-apakah-resolusi-sawit.[23 Oktober 2017].

Gumelar G. 2017. Lawan Resolusi Sawit Uni Eropa, RI Susun Dokumen Deforestasi. https://www.cnnindonesia.com/ekonomi/. [3 Januari 2018].

Hady H. 2004. Teori dan Kebijakan Perdagangan Internasional Buku Kesatu. Ghalia Indonesia. Jakarta.

Kementerian Perdagangan Republik Indonesia. 2017. 10 Komoditi Utama dan Potensial. http://www.kemendag.go.id/id/economicprofile/10-main-and-potential-commodities. [20 Februari 2018].

Maygirtasari T, Yulianto E, dan Mawardi MK. 2015. Faktor-faktor yang mempengaruhi volume ekspor crude palm oil (CPO) Indonesia. Jurnal Administrasi Bisnis (JAB), 25(2): 3-7. http://administrasibisnis.student journal.ub.ac.id/index.php/jab/article/view/1 003.[20 Februari 2018].

Munawaroh S. 2010. Analisis Model Arima BoxJenkins Pada Data Fluktuasi Harga Emas. Skripsi. UIN Malang. Malang.

PASPI [Palm Oil Agribusiness Strategy Policy Institute]. 2017. Mitos vs. Fakta Industri Minyak Sawit Indonesia Edisi Ketiga. PASPI. Bogor.

Radifan F. 2014. Faktor-faktor yang mempengaruhi ekspor CPO Indonesia dalam perdagangan Internasional. Economics Development Analysis Journal (EDAJ), 3(2). http://journal.unnes.ac.id/sju/index.php/edaj. [20 Februari 2018]. 